\title{
Wankelt de onderbouwing van passieve beleggings- strategieën?
}

Prof. Dr. Th.E. Nijman

\section{Inleiding}

Gedurende een groot aantal jaren is vanuit wetenschappelijke hoek gepleit voor passieve beleggingsstrategieën, waarin de beleggingsportefeuille vele jaren dezelfde samenstelling houdt en niet geprobeerd wordt 'de markt te verslaan'. Deze aanbeveling is gebaseerd op drie pijlers: de stelling dat rendementen niet voorspelbaar zijn (de zogenaamde 'random walk theorie'), het Capital Asset Pricing Model (CAPM) dat suggereert dat alle beleggers dezelfde portefeuille van risicodragende activa dienen aan te houden zelfs als het rendement op de marktportefeuille voorspelbaar zou zijn en de hoogte van de transactiekosten. Sinds enige jaren groeit in de literatuur evenwel een nieuwe consensus volgens welke rendementen wel enigermate voorspelbaar zijn. Bovendien is sprake van een heftige discussie betreffende de relevantie voor verwachte rendementen van de risicomaat die door het CAPM wordt gesuggereerd, die bekend staat als 'de bèta'. Als deze twee van de drie genoemde pijlers vervallen, lijkt slechts de hoogte van de transactiekosten als mogelijke motivatie voor passieve strategieën te resulteren. In dit artikel wordt in paragraaf 2 een overzicht gegeven van de recente literatuur betreffende de voorspelbaarheid van rendementen en wordt ingegaan op de vraag of voorspelbaarheid van rendementen strijdig is met de economische theorie. In paragraaf 3 wordt dieper ingegaan op de vraag welke relaties de theorie suggereert tussen rendementen. In deze paragraaf komt ook de discussie betreffende de validiteit van het CAPM ter sprake. Paragraaf 4 besluit met een aantal conclusies. De wederwijdse verwevenheid van de econometrische analyse met de beleggingstheorie die vereist is bij de analyse van de voorspelbaarheid van rendementen en de prijsvorming van financiële activa wordt in dit artikel een aantal malen benadrukt. Een verdere uitwerking daarvan is gegeven in Nijman (1993).

\section{Voorspelbaarheid van rendementen}

Allereerst wil ik ingaan op de vraag of rendementen op financiële activa voorspelbaar zijn. De meest eenvoudige theoretische modellen suggereren dat alle beschikbare informatie over bijvoorbeeld de vooruitzichten van een onderneming al in de huidige aandelenprijs zal zijn opgenomen zodat de beste voorspeller van het toekomstig aandelenrendement een constante zou zijn. Fama (1970) heeft twee varianten van deze laatste stelling geformuleerd: de 'weak form efficiency' hypothese die stelt dat rendementen niet uit hun eigen verleden voorspelbaar zijn en de 'semi-strong form efficiency' hypothese die stelt dat rendementen niet uit enige publiek beschikbare informatie voorspelbaar zijn. Ondanks de beschikbaarheid van grote datasets met historische rendementen van financiële activa is het beantwoorden van de vraag of rendementen voorspelbaar zijn, dus of weak of semi-strong form efficiency gelden, minder eenvoudig dan het op het eerste gezicht lijkt.

Prof. Dr. Th.E. Nijman studeerde Econometrie aan de Vrije Universiteit te Amsterdam. Sinds januari 1993 is hij werkzaam als hoogleraar Econometrie van de Financiële Markten bij de vakgroepen Econometrie en Bedrijfseconomie van de KUB. 


\section{MAB}

Onderzoek naar voorspelbaarheid van rendementen op korte termijn, zeg een dag vooruit, wordt bemoeilijkt door het feit dat slechts een heel klein deel van het rendement eventueel voorspelbaar is, hetgeen bekend staat als het probleem van de lage 'signal to noise ratio'. Data over een langere periode zijn dus nodig om tot uitspraken over voorspelbaarheid te kunnen komen en men zal dus gedwongen zijn additionele aannames te maken over verbanden tussen de voorspelbaarheid in verschillende perioden. Veelal wordt bijvoorbeeld aangenomen dat dezelfde voorspelformule zou werken zowel in bijvoorbeeld 1987 als in 1990 . Een ander probleem dat onderzoek naar de korte termijn voorspelbaarheid van rendementen bemoeilijkt is dat de meest gangbare statistische technieken, zoals de regressietechniek, veel informatie laten liggen. De oorzaak daarvan is dat opeenvolgende rendementen wellicht niet gecorreleerd, maar zeker niet onafhankelijk zijn. Na extreme dagelijkse rendementen, zoals die bijvoorbeeld ten tijde van de beurscrisis in oktober 1987 en oktober 1989 optraden, zijn extreme rendementen, positief dan wel negatief, op de volgende dag veel waarschijnlijker dan in minder hectische tijden. Onderzoek naar de voorspelbaarheid van rendementen dat dit aspect verwaarloost zal veel te snel besluiten dat rendementen voorspelbaar zijn. Correctie van de resultaten van regressie-analyse is mogelijk, ${ }^{2}$ maar indien men bereid is additionele aannames te maken betreffende de clustering van de extreme rendementen zijn analyse technieken beschikbaar die veel efficiënter gebruik maken van de informatie in de data. Een niet onbelangrijk deel van mijn onderzoek in het verleden heeft zich geconcentreerd op het modelleren van deze clustering van extreme rendementen, de zogenaamde conditionele heteroskedasticiteit (zie bijvoorbeeld Drost and Nijman (1992), Nijman and Sentana (1993), Nijman and Palm (1991)). Ik denk dat dit onderzoek een goed voorbeeld is van de vragen die als gevolg van de beschikbaarheid van data op hoge frequenties door de financieringstheorie aan de econometrie gesteld worden.

Onderzoek naar de vraag of rendementen ook op langere termijn, bijvoorbeeld over een horizon van een vijftal jaren, voorspelbaar zijn wordt niet alleen bemoeilijkt door de eerder genoemde problemen, maar bovendien door het feit dat zelfs als data sinds 1925 beschikbaar zijn men slechts over zo'n dertien waarnemingen over vijfjaarsperioden beschikt. Econometristen zijn op zoek naar aannames en bijbehorende technieken die uitsluitsel over eventueel langere termijn voorspelbaarheid van rendementen kunnen geven. Ik denk dan bijvoorbeeld aan technieken om met overlappende steekproeven om te gaan, variance ratio tests, vector-autoregressieve modellen en ARFIMA modellen. ${ }^{3}$

Inmiddels lijkt er ook in de academische georiënteerde literatuur een consensus te groeien dat rendementen tot op enige hoogte voorspelbaar zijn. Recente surveys van deze literatuur worden bijvoorbeeld gegeven door Fama (1991) en Bollerslev and Hodrick (1992). Rendementen blijken voorspeld te kunnen worden uit rendementen in voorafgaande perioden (zie bijvoorbeeld Fama and French (1988), Poterba and Summers (1988), Lo and MacKinlay (1988) en Conrad and Kaul (1989)) en uit fundamentele variabelen als het dividend-rendement, het verschil tussen de geld- en kapitaalmarktrente en het verschil tussen de rente op staatsobligaties en obligaties uitgegeven door ondernemingen (zie bijvoorbeeld Campbell (1987, 1991), Hodrick (1992) en Ferson (1989)). Deze resultaten, die in eerste instantie gevonden werden voor Amerikaanse data, zijn inmiddels bevestigd voor aandelen- en obligatieindices voor een groot aantal landen (zie bijvoorbeeld Harvey (1991), Bekaert and Hodrick (1992) en Campbell and Hamao (1992)). Solnik (1993) heeft laten zien dat met op dergelijke voorspellingen gebaseerde dynamische beleggingsstrategieën inderdaad substantieel hogere gemiddelde rendementen kunnen worden behaald.

Uiteraard is slechts een klein deel van de fluctuaties voorspelbaar. Ook is het goed om op te merken dat de door Fama geïntroduceerde terminologie, waarin markten efficiënt genoemd worden als rendementen niet voorspelbaar zijn, tot veel verwarring kan leiden. Deze terminologie suggereert 


\section{MAB}

dat als rendementen voorspelbaar zijn er iets irrationeel zou zijn aan het gedrag van economische agenten en er geld op straat zou liggen dat men slechts hoeft op te rapen. Velen kennen waarschijnlijk de anekdote van de twee hoogleraren economie uit Chicago die zo overtuigd zijn van de efficiëntie van de economie en van het feit dat er geen geld op straat kan liggen, dat als een van de twee bukt om een briefje van $\$ 100$ op te rapen hij van de ander te horen krijgt dat dat tijdverspilling is omdat dat briefje daar niet echt kan liggen: als het er zou liggen zou het immers al lang door iemand anders zijn opgeraapt. Dergelijke associaties bij het begrip efficiency en bij voorspelbaarheid van rendementen zijn misleidend. Marktefficiëntie is slechts gezamenlijk met een specifiek prijsvormingsmodel te toetsen. Slechts de allereenvoudigste prijsvormingsmodellen suggereren dat rendementen niet voorspelbaar zouden zijn. Meer realistische modellen waarin bijvoorbeeld tijdsvariërende onzekerheid betreffende toekomstige dividenduitkeringen wordt doorvertaald naar tijdsvariërende risico-premies, of tijdsvariërende onzekerheid in het rendement op de marktportefeuille wordt doorvertaald in voorspelbaarheid van het rendement op de marktportefeuille, leiden vrijwel altijd tot voorspelbaarheid van rendementen (vergelijk bijvoorbeeld Abel (1988), Hodrick (1989) en Bollerslev, Engle and Wooldridge (1988)). Hier stelt dus de econometrie juist een vraag aan de financiering om te komen tot modellen van rationeel gedrag als reactie op bijvoorbeeld tijdsvariërende onzekerheid, die leiden tot de empirisch waargenomen voorspelbaarheid van rendementen. Een dergelijk model kan gebruikt worden als alternatief voor de zogenaamde 'fads' modellen die suggereren dat langere termijn voorspelbaarheid gegenereerd wordt door irrationele afwijkingen van een lange termijn evenwicht (Poterba and Summers (1988)).

\section{Prijsvormingsmodellen en de empirische geldigheid van het CAPM}

Laten we nu overstappen van de vraag of rendementen op financiële activa voorspelbaar zijn naar de vraag hoe portefeuilles optimaal kunnen worden samengesteld en de rol die prijsvormingsmodellen voor financiële activa daarbij spelen. Het voorgaande suggereert dat de voorspelbaarheid van rendementen beperkt is. De mening zou dan ook post kunnen vatten dat de keuze van de beleggingsportefeuille onbelangrijk is en even goed zou kunnen plaatsvinden door willekeurig enkele aandelen of obligaties te kiezen, hetgeen bekend staat als 'throwing darts at the financial pages of the Wall Street Journal'. Niets, of in ieder geval niet zo heel veel, is minder waar. Markowitz heeft immers al in 1952 laten zien hoe het risico van een beleggingsportefeuille kan worden gereduceerd door aandelen of obligaties op te nemen waarvan de rendementen weinig correlatie vertonen. Dit argument pleit voor het opnemen in de portefeuille van een aantal obligaties met verschillende looptijden en van aandelen uit diverse landen en/of bedrijfstakken. Ook hier blijken echter een aantal fundamentele vragen nog niet te zijn beantwoord. Allereerst is er bijvoorbeeld het al eerder genoemde feit dat rendementen niet onafhankelijk in de tijd zijn, zoals door Markowitz werd aangenomen. Grote schokken in rendementen blijken aanmerkelijk waarschijnlijker als ook in het recente verleden zich grote schokken voordeden. Met name de multivariate modellering van deze conditionele heteroskedasticiteit, die vereist is om de Markowitz analyse aan te passen voor de afhankelijkheid tussen opeenvolgende schokken, staat nog slechts in de kinderschoenen. ${ }^{4}$ Een tweede onderwerp van onderzoek, ditmaal binnen de financiering, vervangt de aanname van Markowitz dat beleggers uitsluitend in verwachting en variantie van het portefeuille-rendement in de volgende periode zijn geïnteresseerd door algemenere nutsfuncties, waarin bijvoorbeeld ook de scheefheid van de rendementsverdeling een rol speelt, te analyseren in een meer perioden-context. In een wereld waarin opties een steeds grotere rol spelen en waarin het beleggingsbeleid iedere dag kan worden bijgesteld kan deze aanpassing het realiteitsgehalte van de theorie sterk verhogen.

Daarmee zijn we terechtgekomen bij weer een ander veld van onderzoek, en van dwarsverbanden 


\section{MAB}

tussen financiering en econometrie: de prijsvormingsmodellen van financile activa. In deze modellen worden evenwichtsrelaties gezocht tussen bijvoorbeeld verwachte rendementen en risico's van activa er van uitgaande dat geen enkele agent bereid is risico te dragen, zonder daarvoor beloond te worden. Het bekendste voorbeeld van zo'n model is het Capital Asset Pricing Model (CAPM). Als het CAPM geldt zal, ook als rendementen voorspelbaar zijn, een uitsluitend in verwachting en variantie van het portefeuille rendement geïnteresseerde belegger geen systematisch betere voor risico gecorrigeerde beleggingsresultaten kunnen behalen dan een belegger die zich baseert op een passieve marktindex-strategie. In een passieve marktindex-strategie wordt een deel van het vermogen risico-vrij belegd, bijvoorbeeld in deposito's, terwijl het resterende vermogen eenvoudigweg wordt verdeeld over alle resterende beleggingsmogelijkheden in verhoudingen die overeenkomen met de marktwaarde van de fondsen. Naarmate de consequenties van dit model voor de marktparticipanten duidelijker werden, is het aantal index-fondsen, dat wil zeggen fondsen die niet pretenderen 'de markt te kunnen verslaan', sterk toegenomen. De parameter die volgens het CAPM zowel de mate van risi$c o$ in een fonds als de hoogte van het verwacht rendement op dat fonds aangeeft, de zogenaamde bèta, leek tot voor kort een steeds grotere rol te spelen bij beleggingsbeslissingen en een lijst met bèta's per fonds wordt bijvoorbeeld wekelijks in een krant als het NRC-Handelsblad afgedrukt.

Het CAPM is echter slechts geldig onder sterk vereenvoudigende aannames. In de financieringsliteratuur wordt al lang en wordt nog steeds volop gewerkt aan het ontwikkelen van prijsvormingsmodellen voor financiële activa waarin realistischer aannames worden gemaakt. Allereerst kunnen genoemd worden de aan het CAPM verwante evenwichtsmodellen in een mean-variance world waarin bijvoorbeeld sprake is van restricties op 'short-selling', van belastingen (Elton and Gruber (1991), hoofdstuk 12) of van handelsrestricties (Hietala (1987)), maar ook modellen gebaseerd op de Arbitrage Pricing Theory (zie Connor and Korajczyk (1992) voor een recente survey). De jongste ontwikkeling betreft modellen waarin de standaardveronderstellingen van verwachte nutsmaximalisatie en 'time separability' worden losgelaten (zie Weil (1987), Epstein and Zin (1988, 1989), en Bekaert, Hodrick and Marshall (1993)). Bovendien zijn econometristen inmiddels begonnen met het toetsen van de empirische geldigheid van deze nieuwe prijsvormingsmodellen. Epstein and Zin (1991) schatten bijvoorbeeld het door Epstein and Zin (1989) voorgestelde model, terwijl Hansen and Jaganathan (1991) algemene niet-parametrische toetsen voor verwachting en variantie van de intertemporele marginale substitutievoet in een brede klasse van modellen hebben voorgesteld.

Vanuit dit licht bezien is het verrassend dat het artikel van Fama and French (1992), dat nu ongeveer een jaar gelden verscheen in de Journal of Finance, waarin Fama en French een frontale aanval doen op de empirische geldigheid van het CAPM en de relevantie van 'de bèta' voor verwachte returns, zoveel stof heeft doen opwaaien. Naar ik mij heb laten vertellen heeft dit artikel zelfs zoveel aandacht getrokken in de populaire pers in de Verenigde Staten dat naar aanleiding ervan MBA studenten protesteren als deze bouwsteen van het denken in de financiering als verplichte collegestof wordt voorgeschreven. Ik heb overigens niet het gevoel dat Nederlandse studenten zo gevoelig zijn voor de uitkomsten van recent empirisch onderzoek, of het zou moeten zijn dat men op deze wijze een mogelijkheid ziet om de tentamenvereisten wat terug te schroeven.

Zoals gezegd, de aandacht voor het artikel van Fama en French komt mij als nogal overtrokken over. Het CAPM is geldig in een sterk gestileerde wereld, bijvoorbeeld zonder transactiekosten en met zeer specifieke aannames over belastingtarieven, waarin agenten bovendien zich uitsluitend laten leiden door verwachting en variantie van het portefeuille-rendement in de eerstvolgende periode. Ik denk niet dat de theorie zich erg veel zorgen hoeft te maken als dit eerste modelletje dat we aan studenten voorleggen niet in overeenstemming met de feiten blijkt te zijn. Bovendien waren al eerder papers verschenen die claimden 


\section{MAB}

afwijkingen van de voorspellingen van het CAPM te hebben gevonden.

Een aantal van dergelijke claims kan inmiddels op grond van zorgvuldiger analyse als ongegrond ter zijde worden gelegd. Een voorbeeld van een dergelijke door de econometrie ontmaskerde claim op het bestaan van een CAPM anomalie is het zogenaamde overreactie effect dat stelde dat beleggingen in aandelen die in het verleden lage rendementen hadden opgeleverd in de toekomst hogere rendementen zouden opleveren dan door het CAPM kan worden verklaard (zie De Bondt en Thaler (1985, 1987), Chan (1988), Ball and Kothari (1989) en Zarowin (1989)). De additionele verwachte rendementen van 'losers' bleken geheel door hogere CAPM-bèta's te kunnen worden verklaard, mits selection-bias bij het schatten van de bèta's wordt vermeden. Andere afwijkingen van het CAPM, waaronder met name het gegeven dat kleine bedrijven systematisch hogere rendementen opleveren dan het CAPM voorspelt, zijn evenwel inmiddels door vele verschillende onderzoekers op vele verschillende manieren vastgesteld.

Het controversiële karakter van het artikel van Fama en French wordt denk ik dan ook allereerst veroorzaakt door de stijl waarin het artikel geschreven is en vervolgens door de stelling dat bèta niet alleen niet de enige bepalende factor is voor het verwachte rendement, maar zelfs geen significante rol speelt, zeker niet zodra gecorrigeerd is voor verschillen in grootte van de onderneming. De discussie of bèta nu wel of niet een rol speelt bij de bepaling van verwachte rendementen op de markt is denk ik ook weer een goed voorbeeld van een situatie waarin een zorgvuldige empirische analyse kan bijdragen aan de verdere ontwikkeling van de financieringstheorie.

Roll en Ross (1993) hebben er inmiddels op gewezen dat zelfs als het CAPM geldig zou zijn, kleine afwijkingen tussen de werkelijke marktportefeuille en de in de empirische analyse gebruikte benadering daarvoor kunnen leiden tot de conclusie van Fama en French dat er geen enkel verband is tussen bèta en verwacht rendement. Eén van de andere reacties op het paper van Fama en French, dat in de wandelgangen bekend staat als het 'bèta is dead' paper, kwam van Chan en Lakonishok (1992). In een paper getiteld 'Are the reports of bèta's death premature?' claimen zij dat gewoonweg onvoldoende data beschikbaar zouden zijn om tot voldoende preciese uitspraken over het belang van bèta te kunnen komen. Als het juist zou zijn dat een dergelijke centrale voorspelling van de theorie, zelfs met de enorme databestanden die heden ten dage beschikbaar zijn, niet empirisch verifieerbaar of falsifieerbaar zou zijn, is dat uiteraard weinig bemoedigend nieuws voor een pas benoemde hoogleraar Econometrie van de Financiële Markten. Het verheugt mij dan ook u te kunnen stellen dat ik nauwelijks overtuigd ben door de argumenten van Chan en Lakonishok. De kern van mijn bedenkingen is dat de door Fama en French gebruikte test-procedure, die gebaseerd is op de regressie-aanpak van Fama en MacBeth, als gegeven wordt beschouwd. Het is niet moeilijk om in te zien dat deze procedure verre van efficiënt is, zoals recent ook is betoogd door Amihud, Christensen en Mendelson (1992). Deze auteurs gebruiken een iets andere test-procedure en vinden wel een duidelijk significante rol voor bèta, naast de bekende effecten van de grootte van de onderneming en de omvang van het niet gediversificeerd risico.

Tenslotte wil ik nog een opmerking maken over de terminologie 'bèta is dead' die gebruikt wordt in de discussie rond het Fama-French paper en de verwarring waartoe die kan leiden. Ook als de conclusie van het Fama-French paper vast zou staan, betekent dit niet dat bèta irrelevant zou zijn. Ook dan blijft bèta een waardevolle maat voor de mate van risico die beleggen in een bepaald aandeel met zich brengt. Deze bewering volgt direct uit de definitie van bèta als de geschaalde covariantie van het rendement op het actief met het rendement op de marktportefeuille. De discussie betreft slechts de vraag in welke zin additioneel risico ook leidt tot additionele verwachte rendementen. Ook als deze relatie niet zou bestaan is bèta dus van belang bij de portefeuillekeuze. 


\section{Conclusies}

In dit artikel is ingegaan op de validiteit van twee mogelijke onderbouwingen van een passieve beleggingsstrategie: de 'random walk' theorie en het Capital Asset Pricing Model. Recente ontwikkelingen in de literatuur suggereren dat rendementen enigermate voorspelbaar zijn. Bovendien zijn vele prijsvormingsmodellen voorgesteld als alternatief voor het al lang empirisch verworpen CAPM.

De belangrijke vraag of de voorspelbaarheid van rendementen groot genoeg is om rendementen te leveren die opwegen tegen de transactiekosten van minder passieve beleggingsstrategieën lijkt evenwel nog niet beantwoord te zijn.

Evenmin is duidelijk in hoeverre ook de alternatieven voor het CAPM als eigenschap hebben dat passieve strategieën optimaal of vrijwel optimaal zijn. Een goed inzicht in de mate waarin rendementen voorspelbaar zijn en in de eigenschappen en het realiteitsgehalte van de nieuwe prijsvormingsmodellen vereist zowel een uitgebreide kennis van wiskundige en statistische methoden als van de beleggingstheorie. In mijn inaugurele rede (Nijman (1993)) heb ik dan ook gepleit voor een intensievere samenwerking tussen econometristen en bedrijfseconomen bij de bestudering van deze vraagstukken.

\section{Literatuur}

Abel, A.B. (1988), 'Stock prices under time-varying dividend risk: an exact soluiton in an infinite horizon general equilibrium model', Journal of Monetary Economics, 22, pp. 375-393

Amihud, Y., B.J. Christensen and H. Mendelson (1992), 'Further evidence on the risk-return relationship', Working Paper S-93-11, Stern School of Business, New York University

Ball, R. and S.P. Kothari (1989), 'Nonstationary expected returns: implications for tests of market efficiency and seria correlations in returns', Journal of Financial Economics, 25, pp. 51-74.

Bekaert, G. and R.J. Hodrick (1992), 'Characterizing predictable components in excess returns on equity and foreign exchange markets', Journal of Finance, 47, pp. 467-509.

Bekaert, G., R.J. Hodrick and D. Marshall (1993), 'The implications of first order risk aversion for asset market risk premiums', paper presented at the ESF/CEPR workshop on international finance, Maastricht. May 1993.
Bollerslev, T. and R.J. Hodrick (1992), 'Financial markets efficiency tests', Northwestern Working Paper 132, forthcoming in M.H. Pesaran and M.R. Wickens (eds.), The Handbook of Applied Econometrics, I, Macroeconomics.

Bollerslev, T., R.F. Engle and J.M. Wooldridge (1988), 'A capital asset pricing model with time-varying covariances', Journal of Political Economy, 96, pp. 116-131.

Campbell, J.Y. (1987), 'Stock market returns and the term structure', Journal of Financial Economics, 18, pp. 373-400.

Campbell, J.Y. (1991), 'A variance decomposition of stock returns', Economic Journal, 101, pp. 157-179.

Campbell, J.Y. and Y. Hamao (1992), 'Predictable stock returns in the United States and Japan: a study of long-term capital market integration', Journal of Finance, 47, pp. 43-70.

Chan, K.C. (1988), 'On the contrarian investment strategy', Journal of Business, 61, pp. 147-163.

Chan, L.K.C. and J. Lakonishok (1992), 'Are the reports of bèta's death premature ?', University of Illinois at UrbanaChampaign, mimeographed, forthcoming in Journal of Portfolio Management

Connor, G. and R.A. Korajczyk (1992), 'The arbitrage pricing theory and multifactor models of asset returns', Working paper 139 Kellogg Graduate School of Management, forthcoming in Finance Handbook, R. Jarrow, V. Maksimovic and W. Ziemba (eds.)

Conrad, J. and G. Kaul (1989), 'Mean reversion in short horizon expected returns', Review of Financial Studies, 2. pp. 225-240.

De Bondt, W.F.M. and R.H. Thaler (1985), 'Does the stock market overreact?', Journal of Finance, 40, pp. 793-805.

De Bondt, W.F.M. and R.H. Thaler (1987), 'Further evidence on investor overreaction and stock market seasonality', Journal of Finance, 42, pp. 557-580.

Drost, F.C. and Th.E. Nijman (1993), 'Temporal aggregation of GARCH processes', CentER discussion paper 9240, forthcoming in Econometrica.

Elton, E.J. and M.J. Gruber (1991), Modern portfolio theory and investment analysis'. John Wiley, New York, fourth edition.

Engle, R.F., V. Ng and M. Rothschild (1990), 'Asset pricing with a factor ARCH covariance structure: empirical estimates of treasury bills', Journal of Econometrics, 45, pp. 213-238.

Epstein, L.G. (1988), 'Risk aversion and asset prices', Journal of Monetary Economics, 22, pp. 179-192.

Epstein, L.G. and S.E. Zin (1989), 'Substitution, risk aversion and the temporal behavior of consumption and asset returns: a theoretical framework', Econometrica, 57. pp. 937-969.

Epstein, L.G. and S.E. Zin (1991), 'Substitution, risk aversion and the temporal behavior of consumption and asset returns: an empirical analysis', Journal of Political Economy, 99, pp. 236-286.

Fama, E.F. (1970), 'Efficient capital markets: a review of theory and empirical work', Journal of Finance, 25, pp. 383-417.

Fama, E.F. and K.R. French (1988). 'Permanent and temporary components of stock prices', Journal of Political Economy, 96, pp. 246-273.

Fama, E.F. (1991), 'Efficient Capital Markets: II', Journal of Finance, 46 , pp. $1575-1617$ 
Fama, E.F. and K.R. French (1992), 'The cross-section of expected stock returns', Journal of Finance, 67 , pp. $427-465$.

Ferson, W.E. (1989), 'Changes in expected security returns risk and the level of interest rates', Journal of Finance, 44 . pp. 1191-1218.

Geweke, J. and S. Porter-Hudak (1983), 'The estimation and application of long memory time series models', Journal of Time Series Analysis, 4, pp. 221-238.

Granger, C.W.J. and R. Joyeux (1980), 'An introduction to long memory time series and fractional differencing', Journal of Time Series Analysis, 1, pp. 15-39.

Hansen, L.P. and R.J. Hodrick (1983), 'Risk averse speculation in the forward foreign exchange market: an econometric analysis of linear models', in Jacob A. Frenkel, ed. Exchange Rates and International Macroeconomics, Univerisity of Chicago Press.

Hansen, L.P. and R. Jaganathan (1991), 'Implications of security market data for models of dynamic economies', Journal of Political Economy, 99, pp. 225-262.

Harvey, C.R. (1991), 'The world price of covariance risk', Journal of Finance, 45, pp. 111-158.

Hietala, P. (1989), 'Asset pricing in partially segmented markets: evidence from the Finnish market', Journal of Finance, 44, pp. 697-715.

Hodrick, R.J. (1989), 'Risk, uncertainty and exchange rates', Journal of Monetary Economics, 23, pp. 433-459.

Hodrick, R.J. (1992), 'Dividend yields and expected stock returns: alternative procedures for inference and measurement', Review of Financial Studies, 5, 3, pp. 357-386

Newey, W. and K. West (1987), 'A simple positive semi-definite heteroskedasticity and autocorrelation consistent covariance matrix', Econometrica, 55, pp. 729-751.

Nijman, Th.E. and F.C. Palm (1991),'Recent developments in modeling volatility in financial data', CentER discussion paper 9168, forthcoming in Advanced Lectures in Quantitative Economics II, A.J. de Zeeuw, ed., Academic Press, London, 1993.

Nijman, Th.E. and E. Sentana (1993), 'Marginalization and contemporaenous aggregation in GARCH processes', CenIER discussion paper 9312.

Nijman, Th.E. (1993), 'De Data van de Econometrie', inaugurele rede, Tilburg University Press.
Lo, A.W. and C. MacKinlay (1988), 'Stock market prices do not follow random walks: evidence from a simple specification test', Review of Financial Studies, 12, pp. 41-66.

Poterba, J.M. and L.H. Summers (1988), 'Mean reversion in stock prices: evidence and implications', Journal of Financial Economics, 22, pp. 27-59.

Roll, R. and S.A. Ross (1993), 'On the cross-sectional relation between expected returns and betas', John Anderson Graduate School of Management, UCLA.

Solnik, B. (1993), 'The performance of international asset allocation strategies using conditioning information', Journal of Empirical Finance, 1, 1, pp. 33-55.

Weil, P. (1989), 'The equity premium puzzle and the risk free rate puzzle', Journal of Monetary Economics, 24, pp. 401-421.

White, H. (1980), 'A heteroskedasticity consistent covariance matrix estimator and a direct test for heteroskedasticity', Econometrica, 48, pp. 817-838.

Zarowin, P. (1989), 'Does the stock market overreact to corporate earnings information?', Journal of Finance, 44, pp. 1385-1399.

\section{Noten}

1 Dit paper is gebaseerd op een deel van de rede die de auteur op 25 juni jongstleden heeft uitgesproken bij de aanvaarding van het ambt van hoogleraar 'Econometrie van de Financiële Markten' aan de Katholieke Universiteit Brabant. De volledige tekst van de rede is verschenen als Nijman (1993). Adri Verboven en twee anonieme redacteuren van dit blad zijn zo bereidwillig geweest een eerdere versie van dit artikel van kritisch commentaar te voorzien.

2 Bijvoorbeeld door statistische significantie te beoordelen door gebruik te maken van heteroskedasticiteits consistente standaardfouten, zie White (1980).

3 Deze literatuur is zeer omvangrijk. Enkele zeer selectieve verwijzingen zijn Hansen en Hodrick (1983), Newey and West (1987), Hodrick (1992), Granger and Joyeux (1980) en Geweke and Porter-Hudak (1983).

4 De meest recente ontwikkeling is het FACTOR-GARCH model dat is voorgesteld door Engle, Ng and Rothschild (1990). 